\title{
PENENTUAN HARGA POKOK PRODUK DAN PENERAPAN COST PLUS PRICING METHOD DALAM PENENTUAN HARGA JUAL PADA RUMAH MAKAN IKAN BAKAR DABU-DABU LEMONG
}

\author{
Jennifer T. M Moniung ${ }^{1}$, Jantje J. Tinangon ${ }^{2}$, Meily Y. B Kalalo ${ }^{3}$ \\ ${ }^{1,2,3}$ Jurusan Akuntansi, Fakultas Ekonomi dan Bisnis, Universitas Sam Ratulangi, Jl. Kampus Bahu, Manado \\ 95115, Indonesia
}

E-mail: jennifermoniung01229@gmail.com

\begin{abstract}
Determination of the selling price is very influential to maintain the continuity of a company. The selling price offered by the company must be right, because if the selling price offered is too high then the consumer will think twice and switch to another company, and vice versa if the price offered is too low then the costs incurred by the company cannot be covered even will loss. Cost-plus pricing is one of the methods used in determining the price of a product or service to be sold. Cost-plus pricing is a method of determining selling prices by adding expected profits above the full future costs of producing and marketing products. The aim of this research is to find out the Determination of the Cost of Products and the Implementation of the cost plus pricing method in the Determination of the Selling Price in the Dabu-Dabu Lemong Grilled Fish Restaurant. The results showed that there were differences in the analysis results between the two approaches in the cost plus pricing method. The final analysis results obtained, the selling price formed by variable costing is higher than the full costing approach. But when viewed from the cost of production, the variable costing approach produces a lower value compared to full costing. The selling price set by the current owner has a difference if calculated using the cost plus pricing method. Broadly speaking, the selling price set by the current owner is not a favorable price when compared to calculated selling price.
\end{abstract}

Keywords: price of product; cost plus pricing method; rumah makan ikan bakar dabu-dabu lemong; selling price determination

\section{PENDAHULUAN}

Kondisi persaingan di dalam usaha bisnis yang semakin ketat pada jaman ini mengharuskan setiap usaha bisnis untuk meningkatkan kegiatan usahanya dalam setiap bidang, sehingga dapat dikatakan bahwa persaingan menjadi pendorong perkembangan bisnis (Pontoh dan Budiarso, 2018). Guna mengantisipasi persaingan usaha yang semakin ketat, maka banyak sekali usaha-usaha bisnis yang mulai melakukan peningkatan dalam setiap aspek bidang usaha, baik yang berhubungan dengan produk atau jasa dan yang dihasilkan ataupun di dalam internal usaha tersebut.

Salah satu kebijakan yang menyangkut produk adalah penentuan harga jual yang tepat. Kebijakan ini dapat mempengaruhi tingkat laba yang diinginkan oleh perusahaan (Sari dan Nasution, 2018). Beberapa faktor yang mempengaruhi penetapan harga jual adalah biaya dan taksiran laba atau keuntungan yang diharapkan perusahaan. Metode penentuan harga jual yang didasarkan atau berorientasi pada biaya, adalah cost plus pricing method. Metode ini memperhitungkan biaya penuh dan taksiran laba yang diharapkan perusahaan, dalam menentukan harga jual. Penentuan harga jual dipengaruhi beberapa faktor sehingga seringkali diperbaiki dengan melihat perubahan faktor-faktor tersebut.

Pengembangan usaha perusahaan dilakukan perusahaan dengan analisis terhadap pendapatan yang diperoleh beserta biaya-biaya yang dikeluarkan untuk mendapatkan laba 
atau keuntungan yang diharapkan demi keberlangsungan suatu usaha. Karena dari dana yang berasal dari laba/keuntungan usaha inilah yang akan membantu suatu usaha dalam meningkatkan setiap aspek yang diperlukan. Bagian penting dalam meningkatkan laba adalah bagaimana cara yang diperlukan dalam meningkatkan produk yang dihasilkan. Karena semakin meningkatnya laba harus didukung dengan peningkatan penjualan dari produk barang atau jasa yang dihasilkan. Suatu kualitas dan kuantitas dari sebuah produk barang atau jasa yang dihasilkan sangat berpengaruh terhadap peningkatan penjualan, oleh karena itu harus lebih diperhatikan.

\section{TINJAUAN PUSTAKA}

Akuntansi adalah proses identifikasi, pencatatan, dan pengkomunikasian keadaan ekonomi suatu perusahaan kepada pihak-pihak yang berkepentingan. Akuntansi merupakan satu kesatuan sistem informasi pemrosesan data sehingga menghasilkan laporan keuangan yang menggambarkan keadaan perusahaan (Rahman:2013). Sistem akuntansi yang berkaitan dengan ketentuan dan penggunaan informasi akuntansi untuk manajer atau manajemen dalam suatu organisasi dan untuk memberikan dasar kepada manajemen untuk membuat keputusan bisnis yang memungkinkan manajemen akan lebih siap dalam pengelolaan dan melakukan fungsi kontrol (Sodikin:2015).

Akuntansi manajemen menurut Blocher et al. (2013: 5), adalah suatu profesi yang melibatkan pengambilan keputusan manajemen, menyusun perencanaan dan sistem manajemen kinerja, serta menyediakan keahlian dalam pelaporan keuangan dan pengendalian untuk membantu manajemen dalam memformulasikan dan mengimplementasikan suatu strategi organisasi. Akuntansi manajemen merupakan sistem alat yaitu jenis informasi ditujukan pada pihak-pihak internal organisasi seperti manajer keuangan, manajer produksi, manajer pemasaran, dan sebagainya guna pengambilan keputusan internal organisasi (Gunawan et al., 2014). Firmansyah (2014:7) menyebutkan bahwa bidang akuntansi manajemen meliputi penyusunan kegiatan-kegiatan berikut: (1) merancang sistem pengumpulan data; (2) menyediakan data yang relevan dengan keputusan manajemen yang akan diambil; (3) membantu manajemen dalam menentukan pilihan atau alternatif tindakan; (4) membantu manajemen dalam menentukan alternatif yang terbaik untuk memecahkan masalah; dan (5) membantu manajemen dalam merencanakan kegiatan di masa datang.

Menurut Mulyadi (2015), biaya dalam arti luas adalah pengorbanan sumber ekonomis, yang diukur dalam satuan uang, yang terjadi atau yang kemungkinan akan terjadi untuk mencapai tujuan tertentu. Biaya dalam arti sempit diartikan sebagai pengorbanan sumber ekonomi untuk memperoleh aktiva yang disebut harga pokok, atau dalam pengertian lain biaya merupakan bagian dari harga pokok yang dikorbankan didalam suatu usaha untuk memperoleh penghasilan. Biaya adalah nilai kas atau setara kas yang dikeluarkan (dibebankan) untuk mendapatkan barang atau jasa, yang diharapkan dapat memberikan manfaat bagi organisasi pada saat ini maupun dimasa mendatang (Hery, 2015:562). Menurut Mulyadi (2017:12), harga pokok produksi adalah total biaya yang terjadi untuk mengolah bahan baku menjadi produk yang siap untuk dijual. Menurut Supriyono (2016:11), harga pokok produksi adalah semua elemen biaya yang diproduksi baik tetap maupun variabel. Penentuan harga pokok produksi adalah pembebanan unsur biaya produksi terhadap produk yang dihasilkan dari suatu proses produksi atau penentuan biaya yang melekat pada produk jadi dan persediaan barang dalam proses (Mursyidi, 2008:29).

Sari dan Nasution (2018) menyatakan bahwa harga jual yang ditetapkan oleh UD. Maju lebih kecil dari harga jual yang dihitung menggunakan metode cost plus pricing dengan pendekatan penetapan biaya penuh dimana hasil penelitian menunjukkan bahwa selama ini UD. Maju mengalami kerugian. Ikawati (2017) menyatakan bahwa implementasi berbasis akuntansi biaya produk menghasilkan harga produk yang lebih baik dan lebih akurat. Toar et 
al. (2017) menemukan bahwa penetapan harga jual yang ditetapkan oleh Dolphin Donuts Bakery masih menggunakan metode harga jual yang ditetapkan oleh produsen yaitu harga jual yang mengikuti harga pasaran yang telah ditetapkan oleh usaha-usaha dagang sejenis lainnya sehingga perhitungan berdasarkan metode cost plus pricing didapatkan hasil yang berbeda dengan perhitungan menggunakan metode mark up pricing.

\section{METODE PENELITIAN}

Metode analisis yang digunakan dalam penelitian ini adalah metode analisis deskriptif, yaitu suatu metode yang dilakukan dengan cara mengumpulkan, menyajikan, serta menganalisis data sehingga diperoleh gambaran yang cukup jelas tentang masalah yang dihadapi, kemudian ditarik suatu kesimpulan sesuai keadaan yang sebenarnya. Penelitian desktiptif adalah sebuah penelitian yang bertujuan untuk memberikan atau menjabarkan suatu keadaan atau fenomena yang terjadi saat ini dengan menggunakan prosedur ilmiah untuk menjawab masalah secara aktual (Sugiyono:2013). Tempat penelitian ini dilakukan di Rumah Makan Ikan Bakar Dabu-Dabu Lemong dengan alamat Jl. Boulevard 2, Karang Ria, Tuminting, Kota Manado. Proses analisis data dalam penelitian ini yaitu : (1) mengidentifikasi biaya-biaya yang terjadi di Rumah Makan Ikan Bakar Dabu-Dabu Lemong sesuai dengan teori akuntansi yang ada; (2) melakukan perhitungan harga pokok produksi menggunakan metode full costing; (3) menetapkan harga jual dengan menggunakan perhitungan cost plus pricing method; (4) menghitung laba atau keuntungan yang dihasilkan; (5) membahas hasil penelitian; dan (6) mengambil kesimpulan dan memberikan saran.

\section{HASIL PENELITIAN DAN PEMBAHASAN}

\subsection{Hasil penelitian}

Berdasarkan hasil wawancara dengan Bapak Paolo terkait dengan data biaya bahan baku, biaya tenaga kerja langsung, dan biaya overhead pabrik Rumah Makan ikan bakar disajikan pada Tabel 1. Tabel 1 menunjukkan bahwa Rumah Makan Ikan Bakar Dabu-Dabu Lemong Manado mengeluarkan biaya sebesar Rp. 140,606,500 untuk biaya bahan baku. Jika dihitung berdasarkan jumlah porsi yang dihasilkan yaitu sebanyak 4017 porsi/paket maka biaya bahan baku senilai Rp. 35.000 per porsi.

Tabel 1. Biaya bahan baku menu paket tindarung bakar dan paket tuna bakar

\begin{tabular}{clr}
\hline No & \multicolumn{1}{c}{ Bahan Baku } & Biaya (Rp.) \\
\hline 1 & Tindarung & $43,620,000$ \\
2 & Tuna & $56,620,000$ \\
3 & Bumbu & $14,500,000$ \\
4 & Air & $12,180,000$ \\
5 & Beras & $13,686,500$ \\
\hline & Total Biaya Bahan Baku & $\mathbf{1 4 0 , 6 0 6 , 5 0 0}$ \\
\hline \multicolumn{4}{c}{ Sumber: Rumah Makan Ikan Bakar Dabu-Dabu Lemong Manado, 2019 }
\end{tabular}

Tabel 2 menunjukkan bahwa biaya tenaga kerja langsung yang dikeluarkan selama sebulan sebesar Rp. 46.500.000 atau jika dihitung selama satu minggu saat data penelitian diambil sebesar Rp. 6.642.850.

Tabel 2. Biaya tenaga kerja langsung

\begin{tabular}{cccccc}
$\begin{array}{c}\text { Jumlah } \\
\text { Pekerja }\end{array}$ & $\begin{array}{c}\text { Jumlah Jam } \\
\text { Kerja/Bln }\end{array}$ & $\begin{array}{c}\text { Gaji } \\
\text { Bulanan }\end{array}$ & $\begin{array}{c}\text { Upah } \\
\text { per Jam }\end{array}$ & $\begin{array}{c}\text { Upah } \\
\text { per Hari }\end{array}$ & $\begin{array}{c}\text { Upah } \\
\text { per Minggu }\end{array}$ \\
\hline 15 & 345 & Rp. 46.500.000 & Rp. 134.800 & Rp. 1.550.000 & Rp. 6.642.850 \\
\hline \multicolumn{7}{c}{ Sumber: Rumah Makan Ikan Bakar Dabu-Dabu Lemong Manado, 2019 } \\
\hline
\end{tabular}


Tabel 3 menunjukkan bahwa overhead pabrik Rumah Makan Ikan Bakar Dabu-Dabu Lemong Manado sebesar Rp. 11,671,600 yang terdiri dari biaya tetap dan biaya variabel.

Tabel 3. Biaya overhead pabrik Rumah Makan Ikan Bakar Dabu-Dabu Lemong Manado

\begin{tabular}{|c|c|c|c|}
\hline \multirow{2}{*}{$\begin{array}{c}\text { Biaya } \\
\text { overhead pabrik }\end{array}$} & \multicolumn{2}{|c|}{ Jumlah } & \multirow{2}{*}{$\begin{array}{c}\text { Total biaya } \\
\text { overhead } \\
\text { (Rp.) } \\
\end{array}$} \\
\hline & $\begin{array}{c}\text { Biaya tetap } \\
\text { (Rp.) }\end{array}$ & $\begin{array}{c}\text { Biaya variabel } \\
\text { (Rp.) }\end{array}$ & \\
\hline Biaya tenaga kerja tidak langsung & $1,715,000$ & & $1,715,000$ \\
\hline Biaya listrik & & 225,000 & 225,000 \\
\hline Biaya air & & 150,000 & 150,000 \\
\hline Gas Elpiji & & $3,763,000$ & $3,763,000$ \\
\hline Biaya bumbu pelengkap & & $4,934,000$ & $4,934,000$ \\
\hline Biaya bahan penolong & & 530,600 & 530,600 \\
\hline Biaya bahan bakar & & 354,000 & 354,000 \\
\hline Total & $1,715,000$ & $9,956,600$ & $11,671,600$ \\
\hline
\end{tabular}

Sumber: Rumah Makan Ikan Bakar Dabu-Dabu Lemong Manado, 2019

\subsection{Pembahasan}

Tabel 4 menunjukkan bahwa biaya yang dikeluarkan non produksi yang dikeluarkan Rumah Makan Ikan Bakar Dabu-Dabu Lemong Manado sebesar Rp. 8,930,533. Untuk setiap menu makanan yang ada di Rumah Makan Ikan Bakar Dabu-Dabu Lemong Manado pemilik mengharapkan laba masing-masing sebesar 30\% dari total biaya yang dikeluarkan.

Tabel 4. Biaya non produksi Rumah Makan Ikan Bakar Dabu-Dabu Lemong

\begin{tabular}{lr}
\hline \multicolumn{1}{c}{ Biaya non produksi } & Total biaya (Rp.) \\
\hline Biaya Pemasaran & $4,573,333$ \\
Biaya Tenaga Kerja Bagian Pelayanan & $2,500,000$ \\
Biaya Sewa & $\mathbf{7 , 0 7 3 , 3 3 3}$ \\
Total Biaya Pemasaran & $1,857,200$ \\
Biaya Administrasi \& Umum & Total \\
\hline
\end{tabular}

Sumber: Rumah Makan Ikan Bakar Dabu-Dabu Lemong Manado, 2019

Perhitungan harga pokok produksi dan harga jual pendekatan full costing

Biaya bahan baku

Biaya tenaga kerja langsung

Biaya overhead pabrik

Rp. $140,606,500$

Total biaya produksi

Rp. $6,642,850$

Harga pokok produksi per porsi :

Rp. $11,671,600$

Rp. 158.920.950/4,017 porsi $=$ Rp. 39.562 dibulatkan Rp. 39.500

Perhitungan markup:

Biaya pemasaran, administrasi dan umum

Rp. 8,930,533

Laba yang diharapkan $30 \%$ x Rp. 167,851,483

Jumlah

Biaya produksi

Persentase markup

Rp. $50,355,444$

Rp. 59,285,977

Rp. $158,920,950$

Perhitungan harga jual makanan :

Biaya produksi

Markup 37,30\%x Rp 158,920,950

Rp. $158,920,950$

Rp. 59,277,514

Total harga jual

Rp. $218,198,464$

Harga jual per porsi :

Rp. $218,198,464 / 4,017$ porsi $=$ Rp. 54.318 dibulatkan Rp. 54,300

Berdasarkan perhitungan harga pokok produksi dan harga jual dengan pendekatan full costing maka diketahui harga pokok produksi adalah Rp. 39,500 dan harga jual adalah Rp. 54,300. 
Perhitungan harga pokok produksi dan harga jual pendekatan variable costing

Biaya bahan baku

Biaya tenaga kerja langsung

Biaya overhead pabrik variable

Total biaya produksi variable

Rp. $140,606,500$

Rp. $6,642,850$

Rp. 9,956,600

Harga pokok produksi per porsi :

Rp. $157,205,950 / 4,017$ porsi $=$ Rp. 39,135 dibulatkan Rp. 39,100

Rp. $157,205,950$

Perhitungan markup:

Biaya tetap

Laba yang diharapkan $30 \%$ x Rp. 167,851,483

Jumlah

Biaya variabel

Persentase markup

Rp. $1,175,000$

Rp. $50,355,444$

Rp. $51,530,444$

Rp. $9,956,600$

$5.17 \%$

Perhitungan harga jual makanan :

Biaya produksi variable

Rp. $157,205,950$

Markup 5.17\% x Rp. 157,205,950

Rp. 8,127,547

Total harga jual

Rp. $165,333,498$

Harga jual per porsi :

Rp. $165,333,498 / 4,017$ porsi $=$ Rp. 41,158 dibulatkan menjadi Rp. 41,100

Berdasarkan hasil perhitungan harga pokok produksi dan harga jual dengan pendekatan variable costing maka diketahui bahwa harga pokok produksi adalah Rp. 39,100 dan harga jual adalah Rp. 41,100. Berdasarkan Tabel 5 maka diketahui untuk harga pokok produksi dan harga jual penulis mengasumsikan bahwa bahan baku utama yang digunakan oleh kedua menu ini adalah sama. Hal ini didukung dengan data yang diperoleh pada saat penelitian dilakukan. Selain karena kerahasiaan data yang tidak dapat dipublikasikan oleh pemilik, kendala yang lain karena tidak adanya catatan pembukuan yang memadai untuk dapat mengklasifikasikan biaya secara terperinci. Dalam hal ini, penelitian ini menggunakan data catatan yang diberikan oleh pemilik dan juga berdasarkan hasil wawancara. Hasil penelitian yang ada menggambarkan bahwa terdapat perbedaan atas harga pokok produksi dan harga jual yang ditetapkan di Rumah Makan Ikan Bakar Dabu-Dabu Lemong Manado berdasarkan hasil olahan data penelitian ini.

Tabel 5. Perhitungan harga pokok produksi dan harga jual di Rumah Makan Ikan Bakar Dabu-Dabu Lemong Manado

\begin{tabular}{|c|c|c|c|c|c|}
\hline \multirow[b]{2}{*}{ Jenis Menu } & \multirow{2}{*}{$\begin{array}{c}\text { Harga Jual } \\
\text { yang berlaku }\end{array}$} & \multicolumn{2}{|c|}{ Harga Pokok Produksi } & \multicolumn{2}{|c|}{ Harga Jual } \\
\hline & & $\begin{array}{c}\text { Full } \\
\text { Costing }\end{array}$ & $\begin{array}{l}\text { Variable } \\
\text { Costing }\end{array}$ & $\begin{array}{c}\text { Full } \\
\text { Costing }\end{array}$ & $\begin{array}{l}\text { Variable } \\
\text { Costing } \\
\end{array}$ \\
\hline Paket Tindarung Bakar & Rp. 36,500 & Rp. 39,500 & Rp. 54,300 & Rp. 39,100 & Rp. 41,100 \\
\hline Paket Tuna Bakar & Rp. 44,000 & Rp. 39,500 & Rp. 54,300 & Rp. 39,100 & Rp. 41,100 \\
\hline
\end{tabular}

Sumber: Data Olahan, 2019

Harga jual yang berlaku saat ini lebih rendah daripada harga jual berdasarkan metode cost plus pricing. Hal ini dikarenakan harga pokok produksi yang ada lebih besar daripada yang diperkirakan oleh pemilik.Dalam menentukan harga pokok produksi pemilik hanya menggunakan intuisi serta menggunakan perhitungan seadanya tanpa melakukan klasifikasi terhadap biaya-biaya yang dikeluarkan, sehingga pembebanan biaya terhadap produk yang dihasilkan dihitung secara menyeluruh. Penyebab yang lain juga dikarenakan tidak dilakukannya pencatatan keuangan yang memadai sehingga pemilik kesulitan dalam melakukan perhitungan biaya-biaya yang dikeluarkan termasuk dalam menghitung biaya berdasarkan penggolongannya.Berdasarkan data tersebut maka diketahui bahwa harga jual yang ditetapkan oleh pihak Rumah Makan Dabu-Dabu Lemong tergolong rendah jika di bandingkan dengan harga perhitungan cost plus pricing. 


\section{KESIMPULAN DAN SARAN}

\subsection{Kesimpulan}

Kesimpulan atas penelitian ini adalah:

1. Cost plus pricing adalah suatu metode dalam menetapkan harga jual dengan cara menghitung biaya-biaya yang dikeluarkan baik biaya yang berhubungan dengan produksi maupun biaya non produksi dengan menambahkan jumlah biaya tersebut dengan nilai laba yang diharapkan.

2. Terdapat perbedaan hasil analisa diantara dua pendekatan dalam metode cost plus pricing. Harga jual yang terbentuk oleh variable costing lebih tinggi dibandingkan dengan pendekatan full costing. Tetapi jika dilihat dari harga pokok produksi, pendekatan variable costing menghasilkan nilai yang lebih rendah dibandingkan dengan full costing.

3. Harga jual yang ditetapkan oleh pemilik saat ini mempunyai perbedaan jika dihitung dengan menggunakan metode cost plus pricing. Secara garis besar harga jual yang ditetapkan oleh pemilik saat ini bukanlah harga yang menguntungkan jika dibandingkan dengan harga jual yang dihitung dengan metode cost plus pricing.

\subsection{Saran}

Saran dari penelitian ini yaitu :

1. Dalam menghitung harga pokok produksi maupun dalam penentuan harga jual, pemilik dapat menggunakan kedua pendekatan tersebut. Untuk pendekatan full costing dapat digunakan untuk penjualan makanan yang jumlahnya lebih sedikit dari antara menu yang terlaris. Sedangkan untuk metode variable costing dapat digunakan untuk menu makanan yang paling laris, hal ini juga dapat kita gunakan untuk menjaga fluktuasi harga bahanbahan yang sering berubah. Dalam hal ini pemilik dapat menggunakan kedua metode diatas dengan memperhatikan kondisi yang ada.

2. Pemilik perlu melakukan pencatatan pembukuan terhadap keluar dan masuk biaya dan pendapatan serta pemisahan terhadap uang hasil usaha dengan uang pribadi yang dimiliki oleh pemilik.

3. Pemilik perlu untuk melakukan pengendalian terhadap biaya-biaya yang selama ini dikeluarkan, sehingga bisa meningkatkan efisiensi terdapat biaya yang terjadi.

\section{DAFTAR PUSTAKA}

Blocher, E. J., Stout, D. E., \& Cokins, S., G. ( 2013). Manajemen biaya penekanan strategis. Buku 1, Edisi kelima. Jakarta: Salemba Empat

Firmansyah, I. (2014). Akuntansi biaya itu gampang untuk Pemula \& Orang Awam, Cetakan pertama. Jakarta: Dunia Cerdas.

Gunawan, Y., Betri, \& Pratiwi, R. (2014). Pengaruh pengendalian sistem akuntansi manajemen terhadap manajemen kualitas proses pada perusahaan manufaktur berskala besar di Kota Palembang, 1-11. http://eprints.mdp.ac.id/id/eprint/1489

Hery. (2015). Analisis laporan keuangan pendekatan rasio keuangan, Edisi 1 .CAPS (Center For Academic). Yogyakarta: Publishing Service.

Ikawati, A., D. (2017). Penetapan harga jual dengan metode cost plus pricing pada Warung Sederhana 2 Jetis Kulon Surabaya. Jurnal Akuntansi AKUNESA. 5(2). 1-21. https://jurnalmahasiswa.unesa.ac.id/index.php/jurnal-akuntansi/article/view/20460

Mulyadi. (2015). Akuntansi biaya, Edisi 5. Yogyakarta: UPP Sekolah Tinggi Ilmu Ekonomi Yayasan Keluarga Pahlawan Negara.

Mulyadi. (2017). Akuntansi biaya, Cetakan 13. Yogyakarta: UPP Sekolah Tinggi Ilmu Ekonomi Yayasan Keluarga Pahlawan Negara. 
Mursyidi. (2008). Akuntansi biaya: Conventional costing, just in time, dan activity-based costing. Bandung: Refika Aditama.

Pontoh, W., \& Budiarso, N. S. (2018). Ipteks penerapan metode penentuan harga jual normal dalam penentuan harga jual jasa (Studi kasus pada usaha Photocopy Gloria Manado). Jurnal Ipteks Akuntansi bagi Masyarakat, 02(01), 21-30. https://doi.org/10.32400/jiam.2.1.2018.23523

Rahman, P. (2013). Pengantar akuntansi 1 pendekatan siklus akuntansi. Jakarta: Erlangga.

Sari, Y., \& Nasution, L. K. (2018). Analisis penentuan harga jual dengan metode cost plus pricing dan pengaruhnya terhadap laba yang dihasilkan pada UD Maju. Jurnal Akuntansi dan Bisnis, 4(1), 85-96. http://dx.doi.org/10.31289/jab.v4i1.1549

Sodikin, S. S. (2015). Akuntansi managemen: Sebuah pengantar. Yogyakarta: UPP STIM YKPN.

Sugiyono. (2013). Metode penelitian kuantitatif kualitatif dan kombinasi (mixed methods). Bandung: Alfabeta.

Supriyono, R. A. (2016). Akuntansi keperilakuan, Cetakan 1. Yogyakarta: UGM Press.

Toar, O., Karamoy, H., \& Wokas, H. (2017). Analisis perbandingan harga jual produk dengan menggunakan metode cost plus pricing dan mark up pricing pada dolphin donuts bakery. Jurnal EMBA: Jurnal Riset Ekonomi, Manajemen, Bisnis dan Akuntansi, $5(2)$, 2040-2050. https://ejournal.unsrat.ac.id/index.php/emba/article/view/16488 